\title{
Jurnal
}

p-ISSN 2621 - 797X ; e-ISSN 2746-6841 DOI:10.32493

Jurnal Disrupsi Bisnis, Vol.5, No.1, Januari 2022 (53-59)

http://openjournal.unpam.ac.id/index.php/DRB/index

\section{Pengaruh ROA, ROE, Dan NPM Terhadap Harga Saham Pada PT Astra Internasional, Tbk}

\author{
Dandi Nurul Hidayah ${ }^{1 *}$, Alwi $^{2}$ \\ ${ }^{1,2}$ Manajemen, Sekolah Tinggi Ilmu Ekonomi Bima \\ Dandinurulhidayahh17.stiebima@gmail.com ${ }^{1 *}$
}

Received 12 Januari 2022| Revised 20 Januari 2022 | Accepted 31 Januari 2022

*Korespondensi Penulis

\begin{abstract}
Abstrak
Penelitian ini bertujuan untuk mengetahui dan menganalisis pengaruh Return On Asset (ROA), Return On Equity (ROE) dan Net Profit Margin (NPM) terhadap Harga Saham pada PT Astra Internasional,Tbk periode 2005-2019. Penelitian ini berjenis asosiatif. Teknik pengambilan sampling yang digunakan adalah teknik nonprobability sampling yaitu purposive sampling. Teknik pegumpulan data bersifat dokumenter yaitu dengan cara mengunduh data laporan keuangan dan harga saham historis dari BEI. Teknik analisa data yang digunakan yaitu uji asumsi klasik, analisis regresi linear berganda, koefisien korelasi berganda, uji determinasi, uji t dan uji f. Hasil penelitian menunjukan bahwa Secara simultan terdapat pengaruh yang signifikan antara Return On Asset (ROA), Return On Equity (ROE), dan Net Profit Margin (NPM) terhadap harga saham pada PT Astra International,Tbk dengan nilai $\mathrm{f}$ hitung sebesar 4,063 > f tabel 3,59 dan nilai signifikasi sebesar 0,036 <0,05.
\end{abstract}

Kata Kunci: ROA; ROE; NPM; Harga Saham

\begin{abstract}
This study aims to determine and analyze the effect of Return On Assets (ROA), Return On Equity (ROE) and Net Profit Margin (NPM) on stock prices at PT Astra Internasional, Tbk for the period 2005-2019. This research is associative type. The sampling technique used is a non-probability sampling technique, namely purposive sampling, while the reasons for using this sampling technique are: the availability of the data obtained, the use of new/updated data. The data analysis technique used is classical assumption test, multiple linear regression analysis, multiple correlation coefficient, determination test, $t$ test and $f$ test. The results showed that simultaneously there was a significant effect between Return On Assets (ROA), Return On Equity (ROE), and Net Profit Margin (NPM) on stock prices at PT Astra International, Tbk with a calculated $f$ value of $4.063>f$ table 3.59 and a significance value of 0.036 $<0.05$.
\end{abstract}

Keywords: ROA; ROE; NPM; Stock Price

\section{PENDAHULUAN}

Memasuki era globalisasi, di mana perkembangan teknologi dan informasi yang cepat, persaingan dalam dunia usaha menjadi begitu ketat. Satu-satunya jalan untuk tetap bertahan dan bersaing serta mempertahankan eksistensinya di dunia usaha yakni dengan terus tumbuh dan berkembang. Peranan pasar modal sekarang ini dirasakan sangat penting berkaitan dengan fungsi dari pasar modal itu sendiri yakni mempertemukan pihak yang membutuhkan dana dengan pihak yang ingin menanamkan 
modalnya pada pasar modal. Salah satu unsur dalam investasi di pasar modal adalah harga saham. Harga saham mencerminkan juga nilai dari suatu perusahaan ( Deitiana, 2013).

Menurut Sjahril dalam (Rahmadewi dan Abundanti, 2018) pasar modal merupakan ke seluruhan sistem keuangan yang terorganisir termasuk bank-bank komersial dan seluruh perantara dibidang keuangan serta surat-surat berharga jangka panjang dan pendek Fungsi utama pasar modal adalah sebagai sarana pembentukan modal dan akumulasi dana bagi pembiayaan suatu perusahaan/emiten. Banyak jenis surat berharga (securities) dijual dipasar tersebut, salah satu yang diperdagangkan adalah saham. Saham adalah salah produk yang diperjual belikan dipasar modal. Produk lain yang diperjualbelikan di pasar modal adalah obligasi, dan Reksa Dana.

Saham memungkinkan investor untuk meraih return atau keuntungan lebih besar dalam waktu yang relatif singkat (high return), meskipun saham juga memiliki sifat high risk dimana suatu saat harga saham bisa menurun dengan cepat. Jadi saham tersebut memiliki karakteristik high risk dan high return, maka dari itu para investor harus pandai-pandai dalam menganalisis harga saham tersebut karena jika salah dalam menganalisis harga saham, maka investor akan mengalami kerugian yang jumlahnya banyak. Penentuan harga saham salah satunya didasarkan pada kinerja perusahaan. Kinerja perusahaan bisa dilihat dari laporan keuangannya. Laporan keuangan menunjukkan informasi mengenai keadaan suatu perusahaan yang bisa dijadikan sumber informasi bagi pengambilan keputusan. Laporan keuangan perlu dianalisis untuk mengevaluasi kinerja yang dicapai manajemen perusahaan di masa yang lalu, dan juga untuk bahan pertimbangan dalam menyusun rencana perusahaan ke depan. Salah satu analisis laporan yang paling umum dilakukan yaitu analisis rasio keuangan profitabilitas. Rasio profitabilitas merupakan rasio yang menunjukkan kemampuan perusahaan untuk memperoleh keuntungan dari penggunaan modalnya. Rasio Profitabilitas yang digunakan dalam penelitian ini antara lain : Return On Asset (ROA), Return On Equity (ROE), dan Net Profit Margin (NPM).

PT Astra Internasional, Tbk merupakan salah satu konglomerat terverifikasi terbesar di Indonesia. Perusahaan induk investasi ini berdiri sejak tahun 1957 dan sering dianggap sebagai barometer perekonomian Indonesia karena kehadirannya diberbagai sektor (otomotif, agribisnis, alat berat, pertambangan, energi, jasa keuangan, teknologi informasi, infrastuktur dan logistik). Perusahaan ini mulai go publik dan mencatatkan sahamnya di Bursa Efek Indonesia pada tahun 1990 dan berkembang sampai sekarang.

Setiap perusahaan tentu menginginkan harga saham yang terus meningkat karena semakin meningkatnya harga saham akan menarik lebih banyak investor untuk menanamkan modalnya pada perusahaan tersebut. Untuk lebih jelasnya bisa dilihat pada grafik dibawah ini :

Grafik 1. Perkembangan Harga Saham PT Astra Internasional,Tbk (2005-2019)

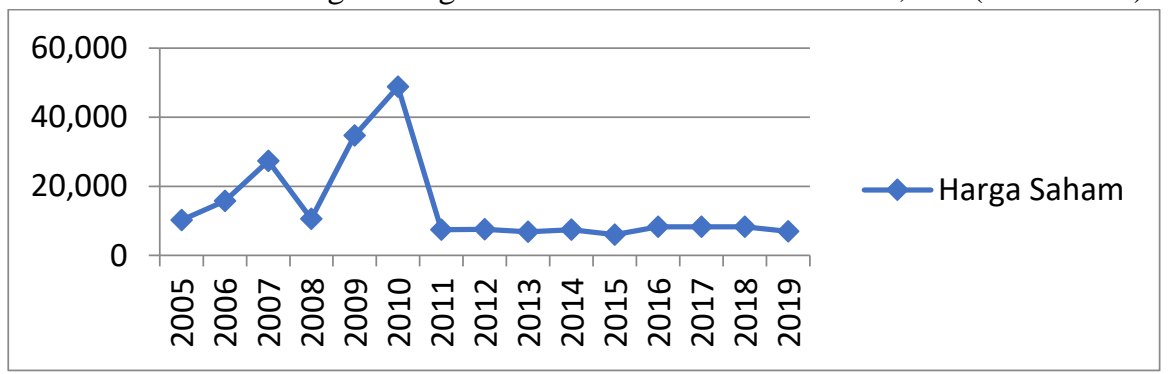

Sumber : (IDX, 2020)

Dari grafik diatas dapat dilihat bahwa perkembangan harga saham PT Astra Internasional,Tbk dari tahun 2005 sampai 2019 mengalami fluktuatif. Pada tahun 2005-2010 harga saham cenderung berfluktuatif pada kisaran angka puluhan ribu yaitu sebesar 10.200, 15.700, 27.300, 10.550, 34.700, dan 48.800. Kemudian pada tahun 2011-2019 harga saham pada PT Astra International Tbk mengalami penurunan yang drastis pada kisaran angka ribuan, yaitu sebesar 7.400, 7.600, 6.800, 7.425, 6.000, 
$8.275,8.300,8.225,6.925$. Hal ini di sebabkan oleh lemahnya konsumsi domestik, tren penurunan harga-harga komoditas,, dan penurunan volume penjualan mobil.

Berdasarkan permasalahan yang di uraikan diatas berkaitan dengan harga saham yang mengalami fluktuatif maka peneliti tertarik untuk meneliti Pengaruh Return On Asset (ROA), Return On Equity (ROE) dan Net Profit Margin (NPM) terhadap Harga Saham pada PT Astra Internasional,Tbk periode 2005-2019.

\section{METODE}

Penelitian ini dilakukan dengan menggunakan jenis penelitian Asosiatif. Penelitian asosiatif menurut (Sugiyono, 2015) yaitu penelitian yang bertujuan untuk mengetahui pengaruh ataupun juga hubungan antara dua variabel atau lebih. Populasi yang digunakan pada penelitian ini yaitu data laporan posisi keuangan, laba rugi dan annual report selama 29 tahun (1990-2019), dengan sampel penelitian selama 15 tahun (2005-2019). Teknik pegumpulan data bersifat dokumenter yaitu dengan cara mengunduh data laporan keuangan dan harga saham historis dari BEI. Peneliti mengumpulkan data secara tahunan melalui laporan keuangan perusahaan dan harga saham yang dipublikasikan dalam bentuk ringkasan kinerja dari tahun 2005 sampai 2019. Teknik analisis data yang digunakan pada penelitian ini yaitu statistik Inferensial, yang akan mempergunakan sejumlah uji-uji seperti uji asumsi klasik yang terdiri dari uji normalitas, uji multikolinearitas, uji heteroskedastisitas, uji autokorelasi,persamaan model regresi berganda ,koefien korelasi, koefisien determinasi, dan uji hipotesis (uji t dan ufi F).

\section{HASIL DAN PEMBAHASAN}

\section{Uji Asumsi Klasik}

Uji Normalitas

Tabel 1. Hasil Uji Normalitas

\begin{tabular}{llr}
\hline & & Unstandardized Residual \\
\hline $\mathrm{N}$ & & 15 \\
Normal Parameters ${ }^{\mathrm{a}, \mathrm{b}}$ & Mean & .0000000 \\
& Std. Deviation & 8705.54911230 \\
Most Extreme Differences & Absolute & .168 \\
& Positive & .166 \\
& Negative & -.168 \\
Test Statistic & & .168 \\
Asymp. Sig. (2-tailed) & & $.200^{\text {c,d }}$ \\
\hline
\end{tabular}

Sumber: Output SPSS Versi 26.

Berdasarkan tabel hasil pengujian normalitas residual sudah berdistribusi normal, yang ditunjukkan dari nilai signifikansi Kolmogorov Smirnov sebesar 0,200 lebih besar dari 0,05. Hal ini berarti data residual terdistribusi normal.

Uji Multikolinearitas

Tabel 2. Hasil Uji Multikolinearitas

\begin{tabular}{|c|c|c|c|}
\hline \multicolumn{2}{|c|}{ Model } & \multicolumn{2}{|c|}{ Collinearity Statistics } \\
\hline & & \multirow[t]{2}{*}{ Tolerance } & VIF \\
\hline \multirow[t]{4}{*}{1} & (Constant) & & \\
\hline & $\mathrm{X} 1$ & .912 & 1.096 \\
\hline & $\mathrm{X} 2$ & .119 & 8.435 \\
\hline & $\mathrm{X} 3$ & .120 & 8.334 \\
\hline
\end{tabular}


a. Dependent Variable: Y

Sumber: Output SPSS Versi 26.

Uji Multikolinieritas bertujuan untuk menguji apakah pada model regresi ditemukan adanya kolerasi antar variabel bebas. Model regresi yang baik seharusnya tidak terjadi kolerasi diantara variabel bebas atau bebas dari gejala multikolinier. Untuk mendeteksi ada atau tidaknya kolerasi antar sesama variabel bebas dapat dilihat dari nilai tolerance dan nilai variance inflation factor (VIF). Berdasarkan tabel pengujian multikolinearitas dapat dijelaskan bahwa nilai tolerance dari ROA (X1) adalah 0,912, ROE (X2) adalah 0,119, dan NPM (X3) adalah 0,120, yang mana hasil nilai tolerance diatas 0,10 . Hal ini berarti tidak ada kolerasi antar variabel bebas.

Hasil perhitungan Variance Inflation Factor (VIF) dari ROA adalah 1,096, ROE adalah 8,435, dan ROE adalah 8,334 menunjukkan nilai VIF dibawah dari 10 yang juga berarti tidak ada kolerasi dari variabel bebas.

Uji Heteroskedastisitas

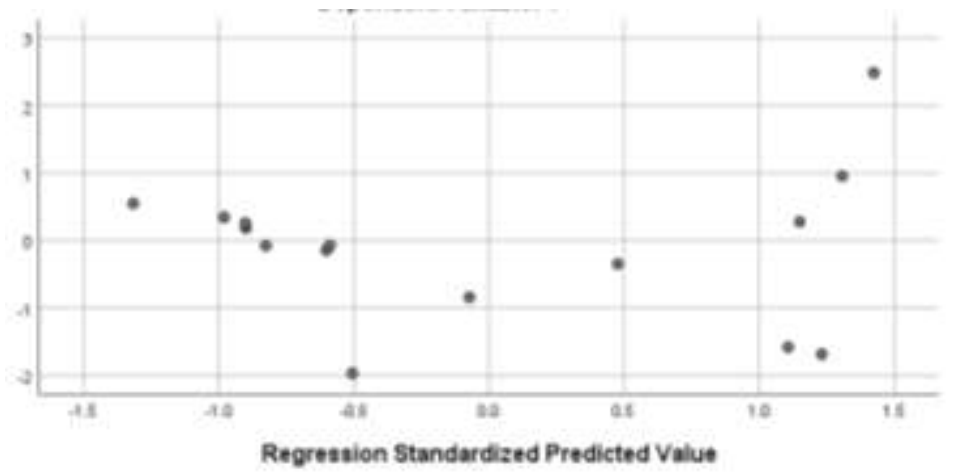

Gambar 1. Scatterplot

Sumber: Output SPSS Versi 26.

Metode yang digunakan dalam penelitian ini untuk menguji heterokedastisitas adalah grafik Scatterplot antara nilai prediksi variable terikat, yaitu ZPRED (Sumbu X) dengan residualnya SRESID (Sumbu Y ). apabila titik-titik menyebar secara acak dan tersebut baik diatas maupun dibawah angka 0 pada sumbu Y, maka tidak terjadi Heteroskesdastisitas pada model regresi, sehingga layak dipakai untuk memprediksi variable terikat berdasarkan masukan variable bebas. Dilihat dari gambar output SPSS diatas bahwa titik-titik tersebut menyebar secara acak dan dibawah angka 0 pada sumbu Y. Maka dapat disimpulan dari uji Heterokedastisitas Scatter Plots diatas tidak terdapat gejala Heterokedastisitas.

Uji Autokorelasi

Tabel 3. Hasil Uji Autokorelasi

\begin{tabular}{lll}
\hline Model & Durbin-Watson & \\
\hline 1 & & 1.961 \\
\hline a. Predictors: (Constant), X3, X1, X2 & & \\
b. Dependent Variable: Y & &
\end{tabular}

Sumber: Output SPSS Versi 26.

Mendeteksi terjadinya autokolerasi dalam penelitian ini dilakukan uji Durbin-Watson dengan melihat kolerasinya. Uji Durbin-Watson dihitung berdasarkan jumlah selisih kuadrat nilai taksiran faktor gangguan yang berurutan. Jika nilai DW terletak antara dU dan (4-dU) maka tidak ada autokorelasi. Berdasarkan tabel diketahui bahwa nilai DW 1,961. Selanjutnya nilai akan dibandingkan dengan nilai tabel DW taraf $\operatorname{sig} 5 \%, \mathrm{~K}=3$ dan $\mathrm{N}=15$ maka diperoleh nilai $\mathrm{dU}=1,750$ dan 4-dU = 2,25. Sehingga dapat disimpulkan bahwa tidak terjadi Autukorelasi karena nilai DW terletak diantara dU dan 4-dU. (dU = 1,750 DW = 1961 4-dU = 2,25). 


\section{Persamaan Regresi Linaer Berganda}

Tabel 4. Hasil Uji Regresi Linear Berganda

\begin{tabular}{llrrr}
\hline \multirow{2}{*}{ Model } & \multicolumn{2}{c}{ Unstandardized Coefficients } & \multicolumn{2}{c}{ Standardized Coefficients } \\
\cline { 3 - 5 } & & \multicolumn{1}{c}{ B } & \multicolumn{1}{c}{ Std. Error } & Beta \\
\hline 1 & (Constant) & 9519.763 & 11924.637 & -.011 \\
& X1 & -1129.764 & 22162.291 & -2.095 \\
& X2 & -283511.038 & 81626.874 & 1.988 \\
\hline
\end{tabular}

a. Dependent Variable: Y

Sumber: Output SPSS Versi 26.

Analisis regresi dilakukan untuk mengetahui bagaimana variabel dependen dapat diprediksi melalui variabel independen. Analisis regresi yang digunakan dalam penelitian ini adalah analisis regresi linier berganda, dari analisis regersi linier berganda dapat dilihat pada tabel diatas: Berdasarkan Tabel diperoleh persamaan regresi $Y=9519,763-1129,764 X 1-283511,038 X 2+391326,366 X 3$

Persamaan regresi diatas dapat dijelaskan bahwa nilai konstanta harga saham sebesar 9519,763 artinya bahwa jika nilai variabel bebas $(\mathrm{X})$ nilainya 0 maka variabel terikat (Y) nilainya sebesar $9519,763$.

Nilai koefisien regresi variabel ROA (X1) sebesar -1129,764 nilai yang negatif menunjukkan adanya hubungan yang negative antara Return On Asset terhadap Harga Saham, jika Return On Asset turun sebesar satu persen sementara variabel lainnya diasumsikan konstan atau sama dengan nol, maka harga saham akan menurun sebesar -1129,764.

Nilai koefisien regresi variabel Return On Equity (X2) sebesar -283511,038 nilai yang negatif menunjukkan adanya hubungan yang negatif antara Return On Equity terhadap Harga Saham. Jika variabel Return On Equity turun sebesar satu persen sementara variabel lainnya dianggap konstan atau sama dengan nol maka Harga Saham akan menurun sebesar --283511,038.

Nilai koefisien regresi variabel Net Profit Margin (X3) sebesar 391326,366 nilai yang positif menunjukkan adanya hubungan yang positif antara Net Profit Margin terhadap harga saham, jika variabel Net Profit Margin meningkat sebesar satu satuan sementara variabel lainnya dianggap konstan atau sama dengan nol maka harga saham akan Naik sebesar 391326,366.

\section{Uji Koefien Korelasi dan Determinasi}

Tabel 5. Hasil Uji Koefien Korelasi dan Determinasi

\begin{tabular}{llrrr}
\hline Model & $\mathrm{R}$ & $\mathrm{R}$ Square & Adjusted R Square & Std. Error of the Estimate \\
\hline 1 & $.725^{\mathrm{a}}$ & .526 & .396 & 9821.184 \\
\hline
\end{tabular}

Sumber: Output SPSS Versi 26.

a. Koefisien Korelasi

Dari tabel diatas diperoleh nilai $\mathrm{R}=0,725$ artinya tingkat keeratan hubungan antara Return On Asset (ROA), Return On Equity (ROE), dan Net Profit Margin (NPM) Terhadap Harga Saham adalah kuat .

b. Koefisien Determinasi

Dari tabel diatas diketahui nilai koefisien determinasi ( $R$ Square) adalah sebesar 0,526 atau sebesar $52,6 \%$. Hal ini menunjukkan bahwa pengaruh variabel independen yaitu ROA,ROE, dan NPM adalah sebesar 52,6\% terhadap variabel dependen yaitu harga saham dan sisanya 47,4\% dipengaruhi oleh variabel lain yang tidak di teliti dalam penelitian ini. 


\section{Uji Parsial (Uji t)}

Tabel 6. Hasil Uji t

\begin{tabular}{llrr}
\hline Model & \multicolumn{2}{c}{ S Sig. } \\
\hline 1 & (Constant) & .798 & .442 \\
& X1 & -.051 & .960 \\
& X2 & -3.473 & .005 \\
X3 & 3.316 & .007 \\
\hline
\end{tabular}

a. Dependent Variable: Y

Sumber: Output SPSS Versi 26.

Nilai signifikansi Return On Asset (X1) adalah sebesar 0,960>0,05 serta nilai thitung sebesar $0.051<$ dari nilai table sebesar 1,796 berarti $\mathrm{H} 1$ ditolak, hal ini menunjukkan bahwa ROA tidak berpengaruh signifikan secara parsial terhadap harga saham. Hasil penelitian ini bertolak belakang dengan penelitian sebelumnya yang dilakukan oleh Rosdian Widiawati Watung dan Ilat (2016) menyatakan bahwa Return On Asset (ROA) berpengaruh positif dan signifikan secara parsial terhadap Harga Saham.

Nilai signifikansi Return On Equity (X2) adalah sebesar 0,005 $<0,05$ serta nilai thitung sebesar $3,473<$ dari nilai $t_{\text {tabel }}$ sebesar 1,796 berarti $\mathrm{H} 2$ diterima, hal ini menunjukkan bahwa ROE berpengaruh signifikan secara parsial terhadap harga saham. Hasil tersebut didukung oleh hasil penelitian sebelumnya yang dilakukan oleh Vireyto dan Sulasmiyati (2017) menyatakan bahwa Return On Equity (ROE) berpengaruh positif dan signifikan secara parsial terhadap harga saham.

Nilai signifikansi Net Profit Margin (X3) adalah sebesar 0,007 $<0,05$ serta nilai $t_{\text {hitung }}$ sebesar 3,316 > dari nilai $t_{\text {tabel }}$ sebesar 1,796 ini berarti H3 diterima, hal ini menunjukkan bahwa NPM berpengaruh signifikan secara parsial terhadap harga saham. Hasil tersebut didukung oleh hasil penelitian sebelumnya yang dilakukan oleh Hidayat (2014) menyatakan bahwa Net Profit Margin (NPM) berpengaruh positif dan signifikan secara parsial Terhadap Harga Saham.

\section{Uji Simultan (Uji f)}

Tabel 7. Hasil Uji f

\begin{tabular}{|c|c|c|c|c|c|}
\hline Model & Sum of Squares & Df & Mean Square & $\mathrm{F}$ & Sig. \\
\hline 1 Regression & 1175726805.146 & 3 & 391908935.049 & 4.063 & $.036^{\mathrm{b}}$ \\
\hline Residual & 1061012194.854 & 11 & 96455654.078 & & \\
\hline Total & 2236739000.000 & 14 & & & \\
\hline
\end{tabular}

Sumber: Output SPSS Versi 26.

Apabila nilai sig $<0,05$ maka terdapat pengaruh variabel $\mathrm{X}$ terhadap variabel $\mathrm{Y}$. Dari tabel diatas dapat diketahui nilai $\mathrm{F}$ hitung sebesar 4,063 > F tabel 3,59 dan nilai signifikasi sebesar 0,036 < 0,05 maka H4 diterima. Hal ini berarti ketiga variabel independen yaitu ROA,ROE, dan NPM secara simultan berpengaruh signifikan terhadap variabel dependen yaitu harga saham. Hasil tersebut di dukung oleh hasil penelitian sebelumnya yang dilakukan oleh Hidayat (2014) menyatakan bahwa Return On Asset (ROA), Return On Equity (ROE), dan Net Profit Margin (NPM) Berpengaruh signifikan secara Simultan terhadap Harga Saham.

\section{SIMPULAN} berikut:

Dari hasil analisis data dan pengujian hipotesis, maka peneliti menarik kesimpulan sebagai 
1. Secara parsial tidak terdapat pengaruh yang signifikan antara variabel Return On Asset (ROA) terhadap harga saham pada PT Astra International, Tbk. Hal ini berarti bahwa investor tidak melihat ROA sebagai keputusan untuk membeli saham.

2. Secara parsial terdapat pengaruh yang signifikan antara variabel Return On Equity (ROE) terhadap harga saham pada PT Astra International, Tbk. Semakin tinggi ROE akan semakin tinggi juga minat investor dalam menanamkan modal pada perusahaan, sehingga harga saham akan ikut naik.

3. Secara parsial terdapat pengaruh yang signifikan antara variabel Net Profit Margin (NPM) terhadap harga saham pada PT Astra International, Tbk. Semakin tinggi NPM akan semakin tinggi juga minat investor dalam menanamkan modal pada perusahaan, sehingga harga saham akan ikut naik.

4. Secara simultan terdapat pengaruh yang signifikan antara Return On Asset (ROA), Return On Equity (ROE), dan Net Profit Margin (NPM) terhadap harga saham pada PT Astra International,Tbk.

\section{Ucapan Terima Kasih}

Peneliti mengucapkan terima kasih kepada pihak yang mendukung dan membantu penelitian ini terutama kepada Bapak Alwi M. Ak selaku dosen pembimbing peneliti yang telah membantu menyusun penelitian.

\section{DAFTAR PUSTAKA}

Darmadji, T. D. (2011). Pasar Modal Di Indonesia. Jakarta: Selemba Empat.

Deitiana, T. (2013). "Pengaruh Current Ratio on Equity Dan Total Asset Turn Over Terhadap Devidend Payout Ratio Dan Implikasi Pada Harga Saham Perusahaan LQ45.” jurnal Bisnis dan Akuansi Vol.15.

Egam, G. E. Y, Ilat, V, Pangerapan, S. (2017). "Pengaruh Return On Asset (ROA), Return On Equity (ROE), Net Profit Margin (NPM), Dan Earning Per Share (EPS) Terhadap Harga Saham Perusahaan Yang Tergabung Dalam Indeks Lq45 Di Bursa Efek Indonesia Periode Tahun 20132015." Jurnal EMBA 5(1): 45-61.

Fahmi, I. (2013). Pengantar Manajemen Keuangan. Bandung: Alfabeta.

------. (2012). Pengantar Pasar Modal. Bandung: Alfabeta.

Hery. (2015). Analisis Laporan Keuangan. Yogyakarta: CAPS.

Hidayat, H. B. (2014). “Analisis Pengaruh Return On Asset (ROA), Return On Equity (ROE) Dan Net Profit Margin (NPM) Terhadap Harga Saham Pada Perusahaan Perbankan Yang Terdaftar Di Bursa Efek Indonesia.” STIM SUKMA MEDAN.

Jannah, W, Rimawan, M. (2020). "Analisis Pengaruh Non Performing Loan (Npl) Terhadap Return on Equity Pada Koperasi Wanita (Kopwan) Kartika Sari Kota Bima.” Jurnal Ekonomi Balance 16(1): 107-14.

Rahmadewi, P. W, Abundanti, N. (2018). "Pengaruh EPS , PER , CR , DAN ROE Terhadap Harga Saham Di BEI." E-Jurnal Manajemen Unud 7(4): 2106-33. https://media.neliti.com/media/publications/254641-none-1206bc2a.pdf.

Sulasmiyati, N. V. (2017). "Analisis Pengaruh Return on Asset, Returnt on Equity, Dan Earning per Share Terhadap Harga Saham (Studi Pada Perusahaan Bank BUMN Yang Listed Di Bursa Efek Indonesia Periode 2006-2016)." Jurnal Administrasi Bisnis. 